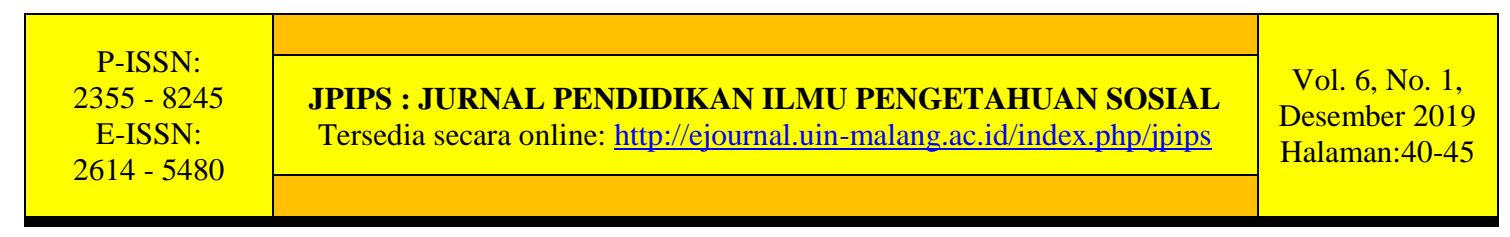

\title{
PENGARUH PERSEPSI DAN RELIGIUSITAS MASYARAKAT TERHADAP SIKAP DAN MINAT SEDEKAH MENGGUNAKAN PEMBAYARAN NON TUNAI
}

\author{
Muhammad Al Faridho Awwal ${ }^{1}$, Dewi Wahyu Setyo Rini ${ }^{2}$ \\ UIN Sunan Kalijaga Yogyakarta \\ 1mafaalial@gmail.com, ${ }^{2}$ dewiwahyusetyor2208@gmail.com \\ Diterima:14-10-2019; Direvisi: 06-12-2019; Disetujui: 30-12-2019 \\ Permalink/DOI: $10.18860 /$ jpips.v6i1.7830
}

\begin{abstract}
Abstrak: Penelitian ini bertujuan mengetahui pengaruh persepsi dan religiusitas masyarakat terhadap sikap dan minat sedekah menggunakan pembayaran non tunai. Metode penelitian menggunakan kuantitatif. Analisis datanya menggunakan uji t dengan aplikasi Smart PLS Versi 3. Hasil penelitian ini menunjukkan nilai uji t kurang dari 0.05. Disimpulkan bahwa adanya pengaruh persepsi dan religiusitas masyarakat terhadap sikap dan minat sedekah menggunakan pembayaran non tunai.
\end{abstract}

Kata Kunci: persepsi; riligiusitas; sikap; minat; pembayaran non tunai

Abstract: This study aims to determine the effect of community perception and religiosity towards the behavior and interest of alms use sedekah cashless. Research methods using quantitative approach. Data analysis using t test with smart application PLS version 3. The results of this study indicate the value of t test is less than 0.05. It was concluded that there was an influence of community perception and religiosity on alms behavior and interest using cashless.

Keywords: perception; religiosity; behavior; interest; cashless

\section{PENDAHULUAN}

Pada era modern seperti sekarang, perkembangan instrumen keuangan Islam telah memasuki era peningkatan kesadaran dari berbagai pihak. Potensi zakat saja telah memasuki nilai Rp 217 triliun (Mardiasmo dalam Azka, 2018), pemerintah terus mengupayakan strategi untuk dapat optimalisasi potensi tersebut. Jika dikaji lebih lanjut, potensi dana sosial ini sebenarnya tidak hanya terbatas pada instrumen zakat. Tetapi juga pada instrumen sedekah dan infak yang memiliki potensi yang sangat tinggi. Mengingat sifat kedua instrumen ini yang lebih menyeluruh untuk digunakan karena pengeluaran dana sosial tidak dibatasi minimal harta yang dimiliki dan minimal dana yang harus diberikan (nisab dan haul). Jenis obyek yang dihimpun juga tidak terbatas pada uang serta penyerahan dana tidak memiliki batasan waktu, sehingga setiap muslim memiliki kesempatan yang sama dalam bersedekah atau berinfak.

Penghimpunan dana infak dan sedekah biasanya identik dengan kegiatan jam 'iyah atau kegiatan pengajian yang melibatkan sekelompok orang. Masjid merupakan salah satu tempat pertemuan dan perhimpunan umat Islam yang dilakukan secara intensif dengan hati dan pikiran yang lebih jernih dari kondisi sebelumnya dan pertemuan lainnya 
(Suryanto, 2016). Peran masjid menjadi sangat strategis ketika dihubungkan dengan kondisi masjid yang selalu membawa kedamaian bagi setiap orang. Mengingat masjid menjadi tempat bermunajat pada Sang Pemilik Hati sehingga tidak heran ketika masjid sering menjadi tempat untuk mendiskusikan setiap kondisi dan keadaan umat di lingkungan sekitarnya. Oleh karenanya, wajar ketika jamaah masjid memiliki basis komunitas yang kokoh. Selain itu, di masjid juga terdapat tokoh karismatik yang biasanya menjadi tokoh tauladan yang dipercaya oleh jamaah sehingga posisinya memiliki pengaruh pengaruh dalam mengkoordinasikan masyarakat di lingkungan tersebut dalam mewujudkan masyarakat yang sejahtera.

Pengguna dompet elektronik (e-wallet) terus mengalami peningkatan setiap tahunnya. Pedagang di jaringan Go-Pay meningkat 90 kali dari sekitar 4.000 pedagang pada Mei 2018 menjadi 360.000 pedagang pada Maret 2019 (Leo Dwi Jatmiko, 2019). Dompet elektronik merupakan tempat penyimpanan uang dalam bentuk aplikasi, sehingga setiap orang dapat mengakses aplikasi ini untuk berbagai kebutuhan dengan mudah. Jenis dompet elektronik terbatas sesuai dengan tujuan penggunaan uang tersebut. Contohnya Go-Pay yang merupakan dompet elektronik dari PT Gojek Indonesia. Fitur ini tidak hanya digunakan untuk pembayaran transportasi online, namun fitur ini sudah bekerja sama dengan berbagai bidang lainnya seperti makanan, pembayaran pulsa, pembelian tiket film, pengiriman barang, dan bidang lainnya. bidangbidang tersebut sudah menjadi kebutuhan manusia dalam mempertahankan keberlangsungan hidupnya. Selain itu, fitur ini juga disertai dengan promo-promo menarik yang membuat masyarakat lebih tertarik untuk menggunakan layanan ini. Pada Oktober 2017 pengguna aktif Go-Pay mencapai 11 juta orang, sedangkan pengguna dompet elektronik lain seperti OVO juga mengalami pertumbuhan mencapai 60 juta orang (Ringkang Gumiwang, 2019).

Pergeseran perilaku masyarakat menuntut semua bidang untuk meningkatkan inovasi pada penyediaan produk dan layanannya. Oleh karenanya, beberapa alternative produk muncul dengan akses yang lebih mudah dan ringan sehingga dapat dijangkau dimana saja dan kapan saja. Hampir setiap penduduk millenial pada usia produktif memiliki aplikasi layanan ini, bahkan terkadang setiap individu memiliki lebih banyak dana di $e$-wallet dari pada uang tunai. Dengan demikian, penulis berupaya merumuskan konsep pembayaran sedekah di masjid yang disinergikan dengan layanan e-wallet. Layanan $e$-wallet akan disinergikan dengan rekening masjid, sehingga penerimaan dana langsung masuk kepada pengelola masjid. Mengingat kebanyakan masyarakat millenial usia produktif lebih sering menyimpan uang dalam bentuk saldo elektronik dari pada uang tunai dan juga lebih sering membawa smartphone-nya daripada dompet ketika pergi beribadah ke masjid. Penelitian ini juga bermula dari kegelisahan penulis yang ketika akan memberikan sedekah namun tidak ada uang cash yang dipegang. Sedangkan yang ada hanya saldo uang yang terdapat di layanan $e$-wallet-nya.

Penelitian ini mengacu pada penelitian Ajeng Nurmalasari pada tahun 2018 dengan judul Faktor-faktor yang Mempengaruhi Minat Penggunaan T-Cash pada Mahasiswa Universitas Islam Indonesia dengan menggunakan metode penelitian kuantitatif melalui teknik analisis regresi linear berganda. Adapun hasil dari penelitian tersebut menunjukkan bahwa variabel kepercayaan secara parsial berpengaruh positif terhadap minat penggunaan T-Cash. Sedangkan persepsi kemudahan, persepsi kebermanfaatan serta keamanan secara parsial tidak berpengaruh terhadap minat penggunaan T-Cash (Ajeng Nurmalasari, 2018). Penelitian lainnya adalah penelitian yang dilakukan oleh Setyo Ferry Wibowo, dkk pada tahun 2015 dalam penelitiannya 
yang berjudul Pengaruh Persepsi Manfaat, Persepsi Kemudahan, Fitur Layanan, Dan Kepercayaan Terhadap Minat Menggunakan E-Money Card (Studi Pada Pengguna Jasa Commuterline Di Jakarta) menghasilkan kesimpulan bahwa semua variabel terkait (Persepsi Manfaat, Persepsi Kemudahan, Fitur Layanan, Dan Kepercayaan) ternyata lolos uji dan berpengaruh (Wibowo, 2015).

Berdasarkan penelitian-penelitian terdahulu dapat dilihat bahwa masyarakat sekarang lebih memilih layanan yang cepat dan mudah salah satunya dalam hal pembayaran. Pada penelitian terdahulu pula dapat dilihat bahwa banyak faktor yang dapat mempengaruhi minat masyarakat terhadap aplikasi atau sistem pembayaran elektronik. Pada penelitian ini, peneliti mencoba menganalisis sikap dan minat masyarakat terutama masyarakat milenial dalam penggunaan pembayaran non tunai untuk bersedekah. Pembayaran non tunai dalam penelitian ini tidak terikat oleh produk apapun, artinya semua pengguna pembayaran tunai termasuk didalam populasi dalam penelitian.

\section{METODE}

Penelitian ini menggunakan kuantitatif dengan mengambil 97 responden melalui teknik purposive random sampling, di mana responden yang dapat mengisi hanya responden yang memenuhi kriteria. Adapun kriteria yang peneliti tetapkan yakni responden yang mengunjungi masjid atau musholla minimal tiga kali dalam seminggu dan sampel merupakan golongan masyarakat milenial. Pengajuan penelitian melalui penyebaran kuesioner yang terdiri variabel lingkungan ekstrernal, lingkungan internal, persepsi, sikap, minat dan religiusitas dalam bentu kuisioner. Analisis datanya menggunakan uji t dengan aplikasi Smart PLS Versi 3.

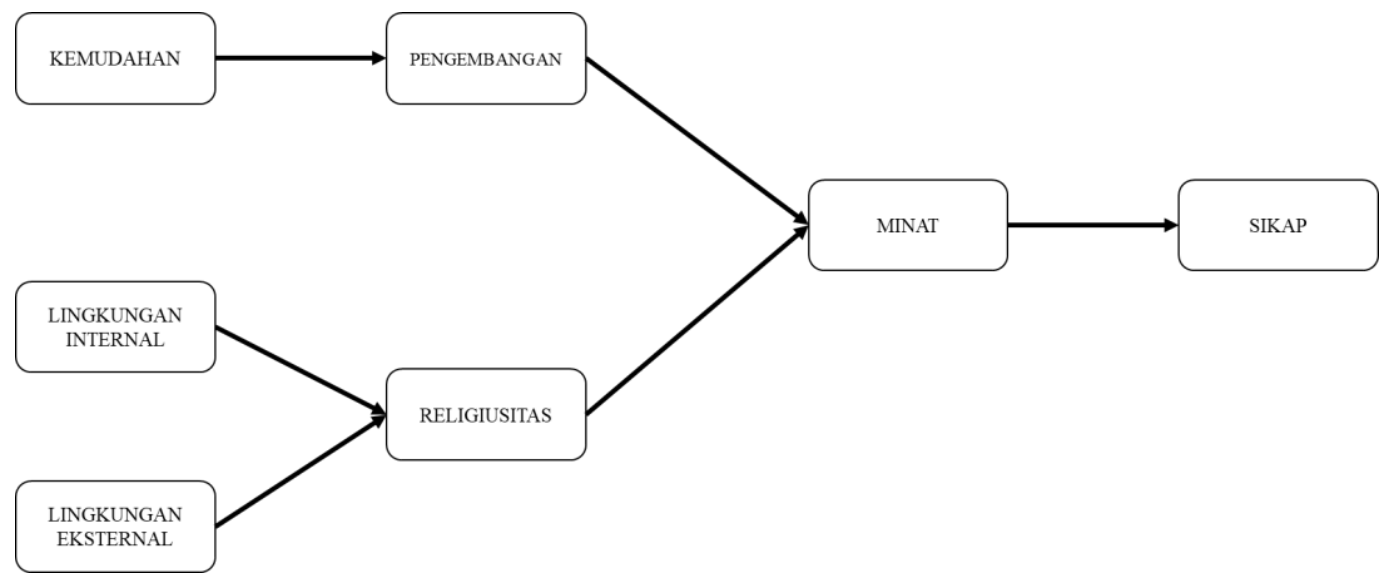

Gambar 1. Kerangka Berpikir dalam Penelitian 


\section{HASIL DAN PEMBAHASAN}

\section{Hasil}

Pengujian pengaruh dilakukan pada uji estimate for path coefficients yakni nilai koefisien jalur atau besarnya hubungan/pengaruh konstruk laten. Berikut hasil uji pada skema dalam penelitian ini:

Tabel 1. Hasil Olah Analisis Pengaruh

\begin{tabular}{|c|c|c|c|c|c|}
\hline . & Original Sample $(0)$ & Sample Mean (M) & Standard Deviation (STDEV) & T Statistics $(|\mathrm{O} / \mathrm{STDEV}|)$ & P Values \\
\hline Lingkungan Eksternal $->$ Religiusitas & 0.420 & 0.427 & 0.106 & 3.966 & 0.000 \\
\hline Lingkungan Internal -> Religiusitas & 0.393 & 0.393 & 0.113 & 3.479 & 0.001 \\
\hline Persepsi Pengembangan -> Sikap & 0.593 & 0.602 & 0.059 & 10.048 & 0.000 \\
\hline Religiusitas -> Sikap & 0.186 & 0.181 & 0.089 & 2.083 & 0.038 \\
\hline
\end{tabular}

Sumber: Hasil Olah Data Smart PLS Versi 3

\section{Pembahasan}

Nilai kelulusan uji pengaruh dapat dilihat pada kolom P-Values, yang mana dapat dikatakan lolos uji ketika nilainya kurang dari 0.05. hasil di atas menunjukkan bahwa semua asumsi sementara peneliti terkait hubungan dan pengaruh pada setiap variabel laten lolos uji. Dapat dilihat bahwa variabel laten persepsi kemudahan berpengaruh signifikan terhadap variabel persepsi pengembangan. Selanjutnya persepsi pengembangan berpengaruh terhadap sikap masyarakat hal ini sesuai dengan Theory of Planned Behavior (TPB) yang dikemukakan oleh Ajzen (1991).

Variabel lingkungan internal berpengaruh signifikan terhadap variabel religiusitas. Karena lingkungan internal memiliki hubungan dalam pembentukan karakter seseorang seperti religiusitas. Sehingga apabila seseorang memiliki lingkungan internal yang baik, maka religiusitas seseorang dapat terbentuk dengan baik.

Begitu pula dengan variabel lingkungan eksternal juga berpengaruh signifikan terhadap variabel religiusitas. Lingkungan internal maupun eksternal, keduanya memiliki pengaruh terhadapt religiusitas. Lingkungan internal seperti keluarga, lingkungan eksternal seperti lingkungan sekolah dan masyarakat tempat tinggal berpengaruh terhadap religiusitas, karena apabila lingkungan eksternal baik, maka religiusitas seseorang akan baik pula.

Selanjutnya religiusitas berpengaruh signifikan terhadap sikap masyarakat yang kemudian variabel laten sikap masyarakat berpengaruh terhadap minat masyarakat. Semakin bagus tingkat religiusitas seseorang, maka hal tersebut dapat mempengaruhi seseorang dalam bersikap, dalam hal ini sikap seseorang kea rah positif. Karena sikap seseorang ditentukan oleh banyak hal, salah satunya adalah religiusitas.

Dalam bersedekah terdapat faktor religiusitas yang dipengaruhi lingkungan internal dan eksternal pada diri seseorang. Warsiyah dalam penelitianya "Pembentukan Religiusitas Remaja Muslim (Tinjauan Deskriptif Analitis)" mengatakan faktor internal merupakan faktor dari dalam diri individu itu sendiri sementara faktor eksternal karena adanya dorongan, pendidikan atau lingkungan sekitarnya. Oleh sebab itu, dalam upaya membentuk religiusitas remaja dibutuhkan faktor internal dan faktor eksternal utamanya faktor lingkungan dan pendidikan. Faktor eksternal seperti lingkungan sekitar dan pendidikan dapat dioptimalkan oleh orang tua, guru maupun masyarakat. Melalui kolom P-Values hasil uji hipotesis dapat dilihat dari kolom T-Statistics, yang mana hipotesis tersebut dikatakan lolos uji ketika nilainya lebih besar dari nilai t-tabelnya. 
Namun dalam hal ini peneliti hanya menggunakan kolom P-Values. Maka dapat disimpulkan adanya pengaruh persepsi dan religiustitas masyarakat terhadap sikap dan minat menggunakan pembayaran non tunai.

Dapat disimpulkan bahwa terdapat pengaruh kuat dari persepsi masyarakat baik tentang kemudahan ataupun pengembangan dan juga religiusitas yang dibangun dari persepsi lingkungan internal maupun lingkungan eksternal terhadap sikap masyarakat yang kemudian menimbulkan minat untuk menggunakan layanan yang peneliti tawarkan. ketika persepsi kemudahan menunjukkan hasil yang positif maka persepsi pengembangan terhadap sedekah online juga akan baik, begitu pula dengan lingkungan internal dan eksternal yang juga mempengaruhi religiusitas seseorang yang pada akhirnya dapat menimbulkan sikap positif dari masyarakat dan minat dalam menggunakan skema sedekah online tersebut.

\section{KESIMPULAN}

Penelitian ini menguji sikap dan minat masyarakat terhadap munculnya layanan pembayaran non tunai untuk bersedekah. Hasilnya menunjukkan bahwa sikap dan minat masyarakat terhadap penawaran layanan pembayaran non tunai dipengaruhi persepsi akan layanan tersebut dan tingkat religiusitas pengguna, oleh sebab itu perlu adanya sosialisasi kepada masyarakat terkait kemunculan layanan ini sebelum layanan ini diterapkan yang mana penyampaian tersebut dapat disampaikan oleh tokoh-tokoh karismatik dengan pendampingan stakeholder lain.

\section{DAFTAR PUSTAKA}

Azka, Rinaldi Mohammad. (2018). Kontribusi Keuangan Syariah Dinilai Makin Signifikan. [Online] Diambil dari https://ekonomi.bisnis.com/read/20180729/9/821921/kontribusi-keuangan-syariahdinilai-makin-signiikan

Ajzen, I. (1991). The Theory of Planned Behavior, Organizational Behavior and Human Decision Processes. A Journal of Fundamental Research and Theory and Applied, 50(2), 179-211

Gumiwang, R. (2018). Jorjoran Adu "Bakar Uang” Go-Pay dan OVO. [Online] Diambil dari https://tirto.id/jorjoran-adu-bakar-uang-go-pay-dan-ovo-c8u1.

J. P, Guilford. (1956). Fundamental Statistics in Psychology and Education. New York: Mc Graw Hill Book Co. Inc.

Jatmiko, Leo Dwi. (2019). 40 Pasar Terima Go Pay, Pedagang Tak Bingung Kembalian, [Online] Diambil dari https://www.google.com/amps/s/m.bisnis.com/amp/read/ 20190404/266/907885/40-pasar-terima-go-pay-pedagang-tak-bingung-kembalian

Dreana, Monica Tirza. (2012). Analisis Faktor-Faktor yang Mempengaruhi Penerimaan Pengguna SIMAWEB di Fakultas Ekonomika dan Bisnis Universitas Diponegoro: Integrasi TAM dan TPB. Skripsi. Universitas Diponegoro.

Nurmalasari, Ajeng. (2018). Analisis Faktor-faktor yang Mempengaruhi Minat Penggunaan T-Cash pada Mahasiswa Universitas Islam Indonesia. Skripsi. Universitas Islam Indonesia.

Pusat Kajian Badan Amil Zakat Nasional. (2018). Outlook Zakat Indonesia.

Rahman, A. (2018). Manfaatkan Teknologi QR Code, Bayar Zakat Lebih Mudah, [Online] diambil dari bisnis.com https://finansial.bisnis.com/read/20180708/90/814047/manfaatkan-teknologi-qrcode-bayar-zakat-bisa-lebih-mudah. 
Rinaldi, Mohammad A. (2018). Kontribusi Keuangan Syariah Dinilai Makin Signifikan. [Online] diambil dari https://ekonomi.bisnis.com/read/20180729/9/821921/kontribusi-keuangan-syariahdinilai-makin-signifikan.

Suryanto, A. (2016). Optimalisasi Fungsi dan Potensi Masjid: Model Pemberdayaan Ekonomi Masyarakat Berbasis Masjid di Kota Tasikmalaya. Jurnal Iqtishoduna, $8(2), 1-27$.

Warsiyah 2018, 'Pembentukan Religiusitas Remaja Muslim (Tinjauan Deskriptif Analitis)', Cendekia, Vol. 16, No 1, Diunduh pada 2019 Mei 07, https://www.researchgate.net/publication/327624292_Pembentuk_Religiusitas_Re maja_Muslim_Tinjauan_Deskriptif_Analitis

Wibowo, Setyo Ferry. (2015). Pengaruh Persepsi Manfaat, Persepsi Kemudahan, Fitur Layanan, Dan Kepercayaan Terhadap Minat Menggunakan E-Money Card (Studi Pada Pengguna Jasa Commuterline Di Jakarta). Jurnal Riset Manajemen Sains Indonesia 6(1), 440-456. 